\title{
Potential of Harvesting Rainwater from Vertical Surfaces
}

\section{Mantas Dobravalskis*, Paulius Spūdys, Juozas Vaičiūnas, Paris Fokaides}

Kaunas University of Technology, Faculty of Civil Engineering and Architecture

Studentu st. 48, LT-51367 Kaunas, Lithuania

${ }^{*}$ Corresponding author: mantas.dobravalskis@ktu.lt

$\Gamma$

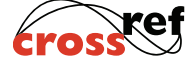

http://dx.doi.org/10.5755/j01.sace.23.2.21606
The water supply chain is under increasing stress as urbanisation and population growth is driving more and more people to move to cities. An increasing amount of city planners are now looking for alternative water resources, rainwater being one of them. There are multiple benefits to on-site water collection, storage and use, as proven by multiple published studies and successful projects around the world; however, rainwater harvesting $(\mathrm{RWH})$ has remained a niche technique, not seen as part of the mainstream. One of the reasons for this is that, traditionally, rainwater has only been collected from rooves and other horizontal surfaces, and then transferred and stored in various subsurface holding tanks. This method of RWH is dated and not very effective. Furthermore, rainwater is one of the purest water sources, but when collected from horizontal surfaces, it gets polluted with particles that have settled on those surfaces. As a result, RWH in this way can be used only for specific purposes. In order to fully utilise this natural resource, to enable the creation of sustainable cities, we must devise a new method for collecting rainwater. One aspect of RWH that has not yet been deeply explored is collecting it from vertical surfaces. Although some abstract studies have already been conducted, concerning water runoff from vertical surfaces, no studies have evaluated the possibility of harvesting and using such water.

In this paper, the impacts of different sets of conditions and variables on the performance of RWH systems mounted on vertical surfaces, such as building facades, are compared. In addition, this study aimed to evaluate the potential of such systems to be used in real-world projects around the globe. To accurately measure collected rainwater, an experimental stand was constructed. This stand consisted of a mechanism that allowed the water-collecting surface and its parameters to be changed, whilst also measuring various aspects of the weather and the amount of water that was successfully harvested. The experiments were conducted in both a controlled environment (laboratory) and under real (natural) conditions.

The results of this study provide a more accurate evaluation of how vertical RWH systems can be implemented in real-life projects around the globe and show how natural conditions and the surfaces used can change the effectiveness of RWH.

Keywords: rainwater harvesting, sustainable cities, vertical surfaces, water source, wind driven rain.

Under real-life conditions, all rain has a horizontal velocity due to wind acting upon rain droplets. Such rain is called wind-driven rain (WDR). Even though most building facades are completely vertical, rain still hits them due to this reason. This provides an opportunity for collecting such rain from vertical surfaces, allowing it to be used in water supply systems.

On the other hand, WDR is not only an opportunity, but also a threat. Multiple studies have showed that rainwater can do serious damage to building materials and their longevity (Abuku, Janssen, Roels, 2009; Blocken, Deromeb, Carmeliet, 2013). All porous construction materials can hold a maximum amount of moisture, but when this threshold is reached or exceeded, serious damage
JSACE $2 / 23$

Potential of Harvesting Rainwater from Vertical Surfaces

Received 2018/09/24

Accepted after revision 2018/11/03

\section{Introduction}

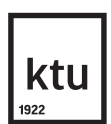

Journal of Sustainable Architecture and Civil Engineering Vol. 2 / No. 23 / 2018 pp. $79-85$ DOI 10.5755/j01.sace.23.2.21606 
can occur. Frost damage due to expanding water, the discolouration of facade materials and structural degradation are all caused by excess water in facades (Kyllingstad et al., 2010).

There are multiple benefits to harvesting rainwater from building facades, for example cleaner surface and more unused space when compared to roofs. But there have not yet been meaningful or comprehensive studies in this field. Evaluating the WDR harvesting potential from vertical surfaces requires accurate RWH measurement datasets that follow guidelines to guarantee precise and reliable data. Such information would also be of use in future studies, and in the development of such wind-driven RWH systems for use in real buildings around the world.

This study aimed to precisely measure the amount of rainwater that could be successfully collected from vertical surfaces, such as building facades. To that end, a specialized WDR harvesting stand was developed and manufactured. A first series of experiments was conducted in the laboratory using simulated rain. The experimental stand had the ability to change the angle of the vertical surface by up to $7.5^{\circ}$. Both successfully harvested rainwater and runoff were measured. Load cells were used as primary parts of the measuring equipment. These can measure mass changes, as times goes by, and allowed us to observe how effective the system was, as well as how the rain intensity impacted the effectiveness of the system. In the Methods section, a detailed description of the experimental stand is given, alongside photos and drawings, as well as of the main control unit. This section also contains an explanation of the methodology that was used to analyze the data collected during the experiments. The Results section presents the parameters of the simulated rain, the measured RWH data and the results of the data analysis. These results show the percentages of rainwater that can be harvested, of water runoff and of rainwater that splashed off and could not be harvested.

Methods

The experimental stand for measuring the rainwater collection rate was constructed. This is shown in Fig. 1, and is composed of two main parts - the RWH stand and the main control unit.

\section{Fig. 1}

System used for wind driven rainwater harvesting from vertical surfaces (a - RWH assembly, b - base, c - main control unit, $d$ - data logging process) a)

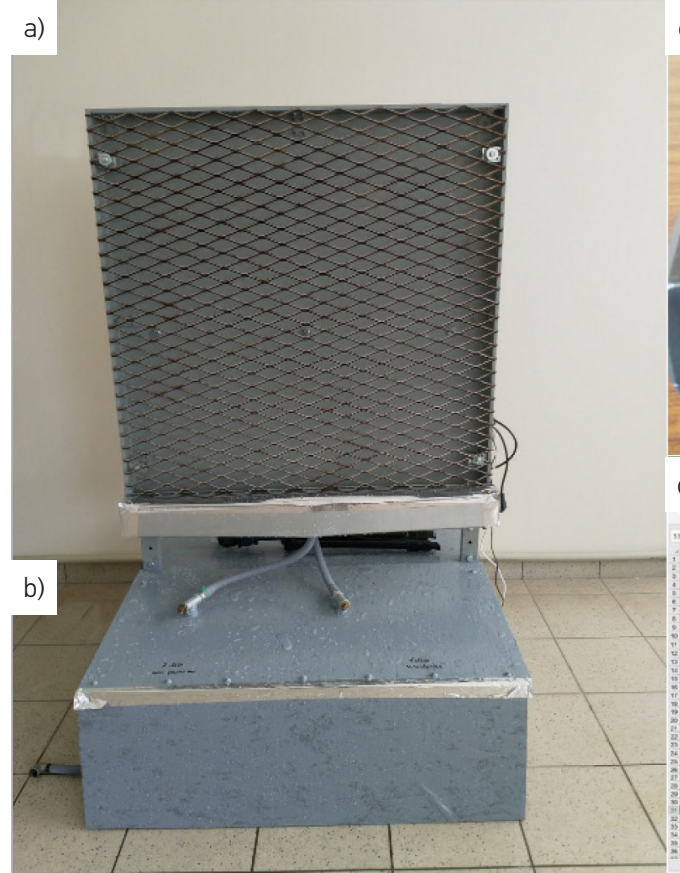

c)

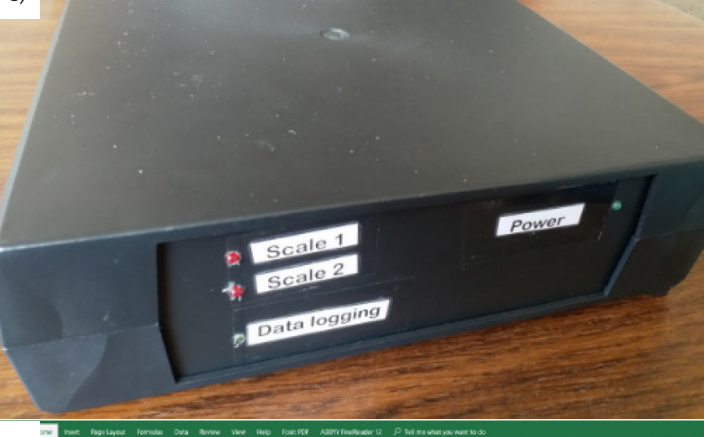

d)

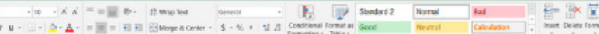
(n) 


\section{Experimental stand}

The experimental stand for RWH comprises of a RWH assembly(a) and a base(b) (Fig. 2).

The main purpose of the base was to hold the water-measuring scales(c) and ensure stability of the RWH assembly. The base measured $1000 \mathrm{~mm} \times 970 \mathrm{~mm} \times 300 \mathrm{~mm}$. Due to the stand comprising of two parts, the base had two sockets that enabled easy installation of the RWH assembly. Each side of the base was covered in aluminum sheeting and cement particleboard. This was required to make sure that the mass measuring equipment in the base would not be exposed to water droplets splashing from the vertical surface of the stand, or from other excess water that had not been harvested. Cement particleboard was used to increase the mass of the base, so that it was more stable and could be used outside in windy conditions in the study planned for natural outdoor conditions.

b)

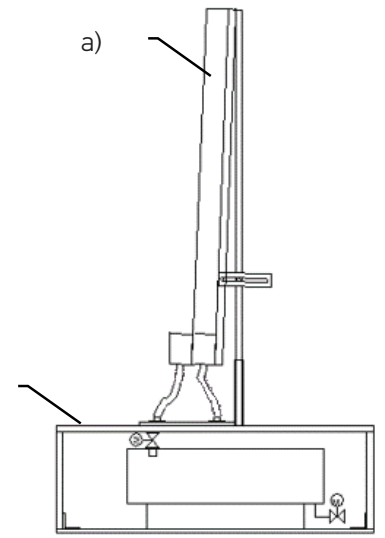

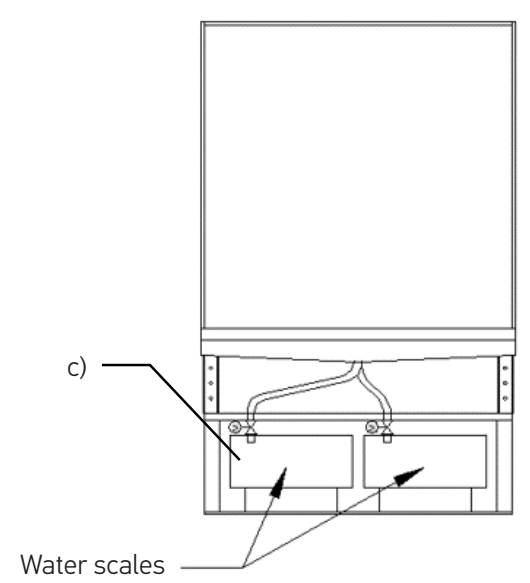

Water scales
Fig. 2

Experimental stand (a - RWH assembly, b - base, c - water scales for harvested rainwater and runoff)
The RWH assembly imitates a real building facade, with a system for wind-driven RWH. This is illustrated in Fig. 2. It has additional equipment for transporting the harvested rainwater to measuring devices at the base. This part of the experimental stand was constructed from a hermetic box, with the front side covered with the facade panel being tested. The depth of the box was $58 \mathrm{~mm}$. Water that permeated through the facade panel ran down the box and into a gutter that had an outlet hose running to Scale 1 - the scale that tracked the mass of harvested rainwater. Rainwater runoff that flowed down the panel surface and did not enter the box was collected by another gutter that was mounted on the outside of the box. Water from this gutter went to Scale 2, which measured rainwater runoff. A section of RWH assembly is shown in Fig. 3.

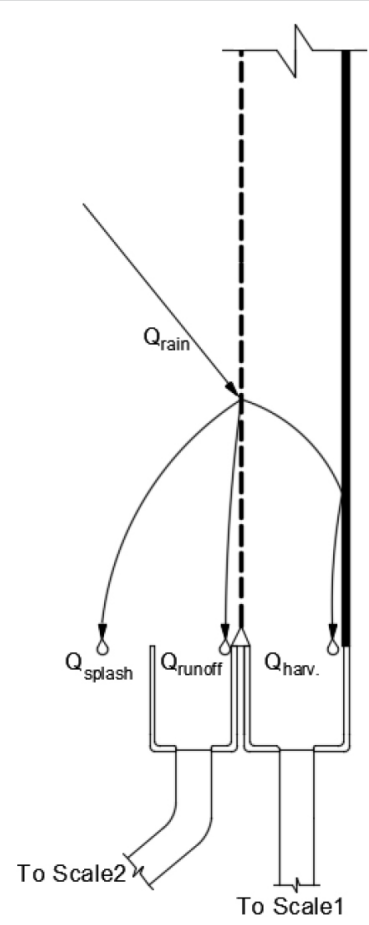

\section{Fig. 3}

Wind driven rainwater harvesting system section also showing ways that rain droplets can act upon falling on the facade panel 


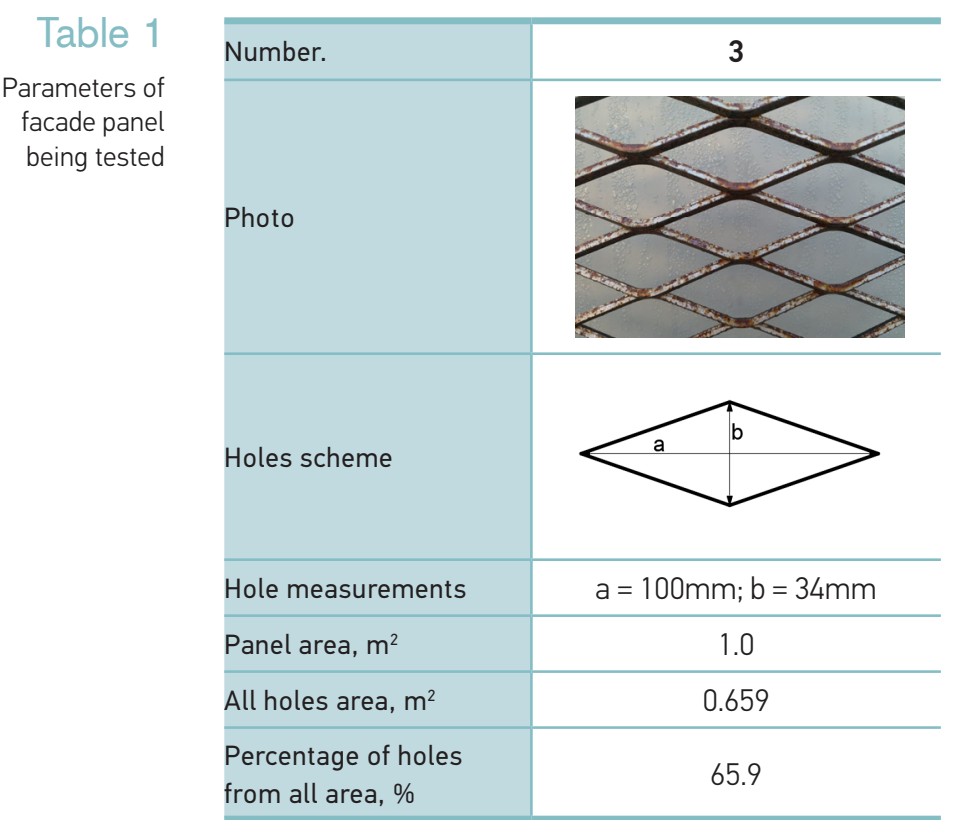

One architectural panel was tested - a type commonly used in modern architecture, which was supplied by a company that supplies metal facade panels for construction of various buildings. Using an existing panel proved that the suggested RWH system could be implemented in various types of buildings without limitations on the design or materials being used. The panel tested was made of expanded metal; its full parameters are shown in Table 1.

Water was sprayed though a fixed water hose nozzle that was fixed to a tripod so that it could be adjusted easily while still remaining stable when spraying water. All of the experiments where conducted with the water nozzle in the same position. The water nozzle was connected to

the city water supply by a hose. The nozzle valve was set to one position, and kept the same for all experiments. Only the main water supply valve was closed and opened during the experiments.

For the water storage, two plastic boxes were used. Each of these could hold up to $40 \mathrm{l}$ of water. A special pipe fitting was fixed at the top of the box to allow water from the gutters to flow into it. At the base of each box, a metal end cap was fitted for easy and fast emptying of the boxes.

\section{Main control unit}

The main control unit was constructed from off-the-shelf components. Arduino was selected as the main controller of the system that all other components were connected to. A layout of main control unit components is shown in Fig. 4. The system used two separate scales - Scale 1 to measure the weight of the rainwater that was successfully harvested during the experiment, and Scale 2 that measured the runoff water from the RWH surface (facade panel).

Both scales had identical construction and components. As the base for the scale, modular metal brackets were used that were put together using rivets. The main parts of the scales were the load cells. Due to their wide availability and high accuracy, strain-gauge-type load cells were selected. Each cell had a maximum capacity of $10 \mathrm{~kg}$. In order to achieve the required scale capacity, multiple load cells were used per scale. In order to accurately read the changes in the electrical

Fig. 4

Main control unit schematic

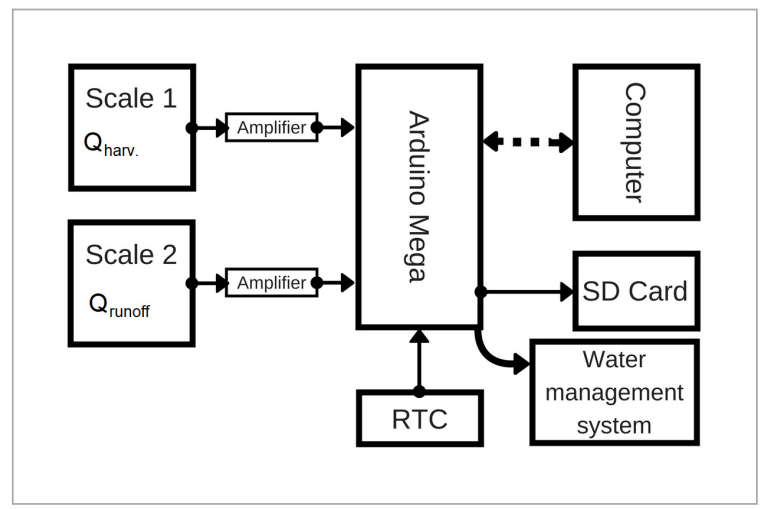
signals generated by the deforming load cell, specialized HX711 amplifiers were used. The amplified signal was measured by the Arduino microcontroller, and then was interpreted as mass. The technical specifications of the load cells used are shown in Table 2.

All load cells are similar but have minor differences due to the manufacturing process. In order to accurately measure weight, all of the load cells needed to be calibrated, which was done by special 


\begin{tabular}{l|c|c}
\hline Capacity & $\mathrm{kg}$ & 10 \\
\hline Safe overload & $\% \mathrm{FS}$ & 120 \\
\hline Ultimate overload & $\% \mathrm{FS}$ & 150 \\
\hline Combined error & $\% \mathrm{FS}$ & \pm 0.05 \\
\hline Non-linearity & $\% \mathrm{FS}$ & \pm 0.05 \\
\hline Repeatability & $\% \mathrm{FS}$ & \pm 0.03 \\
\hline Creep & $\% \mathrm{FS} / 3 \mathrm{~min}$ & \pm 0.05 \\
\hline Operating temperature range & ${ }^{\circ} \mathrm{C}$ & $-10-+55$ \\
\hline
\end{tabular}

Table 2

Technical specifications of load cells that are used in scales

code. This code allowed a calibration factor to be set for each load cell individually. Tests were performed using known-mass objects to test the accuracy of each scale. The primary results showed inaccuracies of up to $2 \%$.

All the data processing and collecting was performed by an Arduino Mega board, which is an open-source development board that allows the combination and use of different kinds of sensors and devices. All the load cell outputs were connected to Arduino after passing through amplifiers. The resistance readings of the load cells were then interpreted as mass values. As there were multiple load cells per scale, several values were added to get a complete reading from each scale. A safety mechanism was also implemented to warn the user when the scales were close to being overloaded, as overloading load cells makes them deform past their plasticity, making further measurements unacceptable.

Data from the scales needed to be transferred to a computer for further analysis. A serial port connection was established between a computer and the microcontroller using Arduino Ide software. To make the data easy to work with, and to perform the required calculations, it was transferred in real time straight into Microsoft Excel. This was done by using specialized software called PLX-DAQ. Mass and accurate times were tracked. The main control unit also had an SD card slot implemented. This was used as a backup, so that even if the computer was not functioning, all of the information would still be stored on the SD card and could later be imported to the computer. To accurately track time, it was collected from a real-time clock (RTC). Thanks to having the exact time attached to the data being collected, the data was very easy to work with and analyze later. This functionality will be very helpful in experiments conducted under real (natural) conditions. This will allow data gathered by our experimental stand to be easily compared with weather station data.

For the laboratory experiments, manual water emptying was used. For experiments conducted outside, Arduino was also connected to relays that would control the water management system that empties the water tanks automatically once they were full, or when it stopped raining. This made this system fully automated - a good solution for long-term experiments under real (natural) conditions.

\section{Experiment description}

All experiments in the first phase of the study were conducted in the laboratory, under the same conditions. No wind was used during the experiments, but angle of the water flow hitting the panel was set so it simulates winds effects on rain. The experimental stand was mounted in place. The water nozzle stand was placed $95 \mathrm{~cm}$ from the facade panel. The angle of the water droplets hitting the facade panel were calculated to be between $50^{\circ}$ and $65^{\circ}$. Because of the type of water nozzle used, different areas of droplets were hitting the facade at different angles (Fig. 5). The water supply was set to one position, and all of the tests experienced the same intensity of simulated rain. The rain pattern hitting the facade panel can be seen in Fig. 5. The area of rain spatter was 
Fig. 5

a) Water hitting panel pattern;

b) Water droplets hitting facade panel angles a)

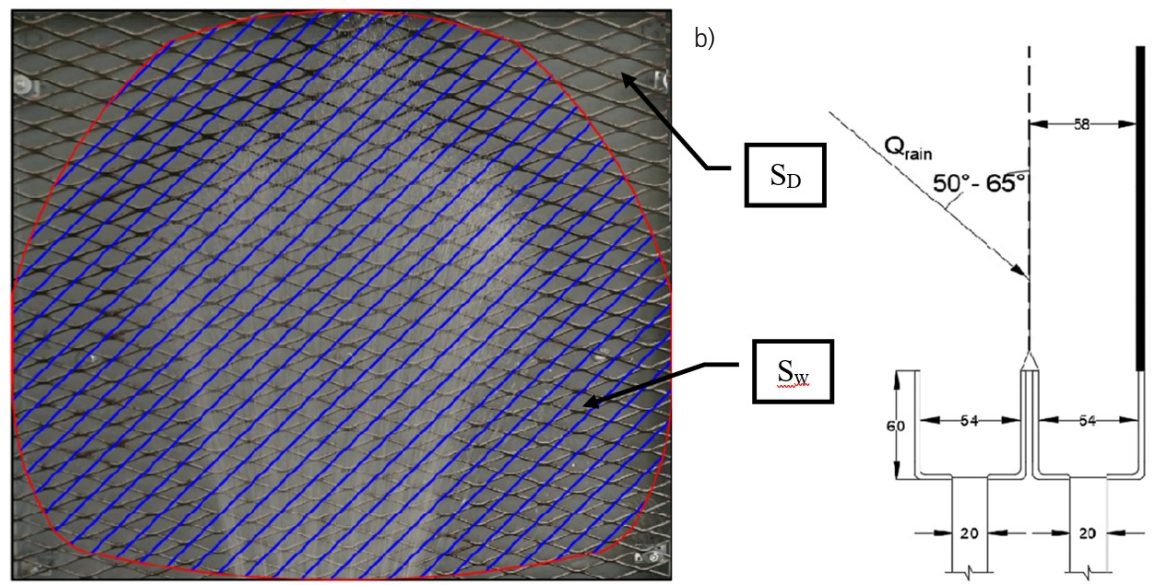

approximately $\mathrm{S}_{\mathrm{w}}=0.76 \mathrm{~m}^{2} . \mathrm{S}_{\mathrm{D}}=0.24 \mathrm{~m}^{2}$ was the area that was not hit by any of the water during the experiments. The nozzle was set in this way to make sure that $100 \%$ of the water sprayed hit the facade. This way, the amount of water that splashed off the facade, and so did not end up in in the RWH system, could be calculated.

Firstly, experiments using fully vertical surfaces were conducted. Four experiments, lasting from 1:00 to 3:30 minutes, were conducted. After each experiment, the water tanks were manually emptied, then everything was reset to the starting position, and the next experiment was conducted. This was done with all the panels. Two more experiments were conducted with the experimental stand set at an angle. The first angle tested was $2.5^{\circ}$, and then $7.5^{\circ}$. All data from the tests were transferred, in real time, from the main control unit to a computer, and saved in Microsoft Excel. Data was collected each second. After all the data was collected, it was used to analyze the effectiveness of the system.

\section{Data analysis}

The experimental stand collected and measured three components of the rainwater (Fig. 3 ) - harvested rainwater $\left(Q_{\text {harv }}\right)$, water runoff $\left(Q_{\text {runoff }}\right)$ and water that had splashed off the facade panel $\left(Q_{\text {splash }}\right)$. The amount of water that had splashed off was calculated by subtracting the harvested rainwater and runoff water mass from the total water amount that was sprayed on to the experimental stand. The total water mass that was sprayed on to the facade was calculated by performing an additional test on the spray nozzle. For a measured amount of time, water was sprayed into a bucket, then the amount of water that was collected during that time period was measured. Chronometer and one of the scales from the experimental stand were used for these measurements. Calculations were then made to determine the mass of water that was sprayed on to the RWH experimental stand in 1 second. To find out the total water quantity sprayed during each test, a multiplication of the test duration and the rain intensity was made. With this information, all further calculations that were needed to evaluate the effectiveness of this RWH system could be made. The main results we were looking for were the amount of water that was harvested, runoff or splashed. All of these components of the RWH were calculated in both quantity in liters and as a percentage of all water that was sprayed on to the surface.

During the experiments, the harvested and runoff rainwater were constantly monitored. The results showed stability and linear growth, as plotted in Fig. 6. All four experiments showed similar water mass growth rate with on average only $3 \%$ difference between all the experiments, so it can be concluded that the data was collected accurately, and no errors occurred during the experiments. 


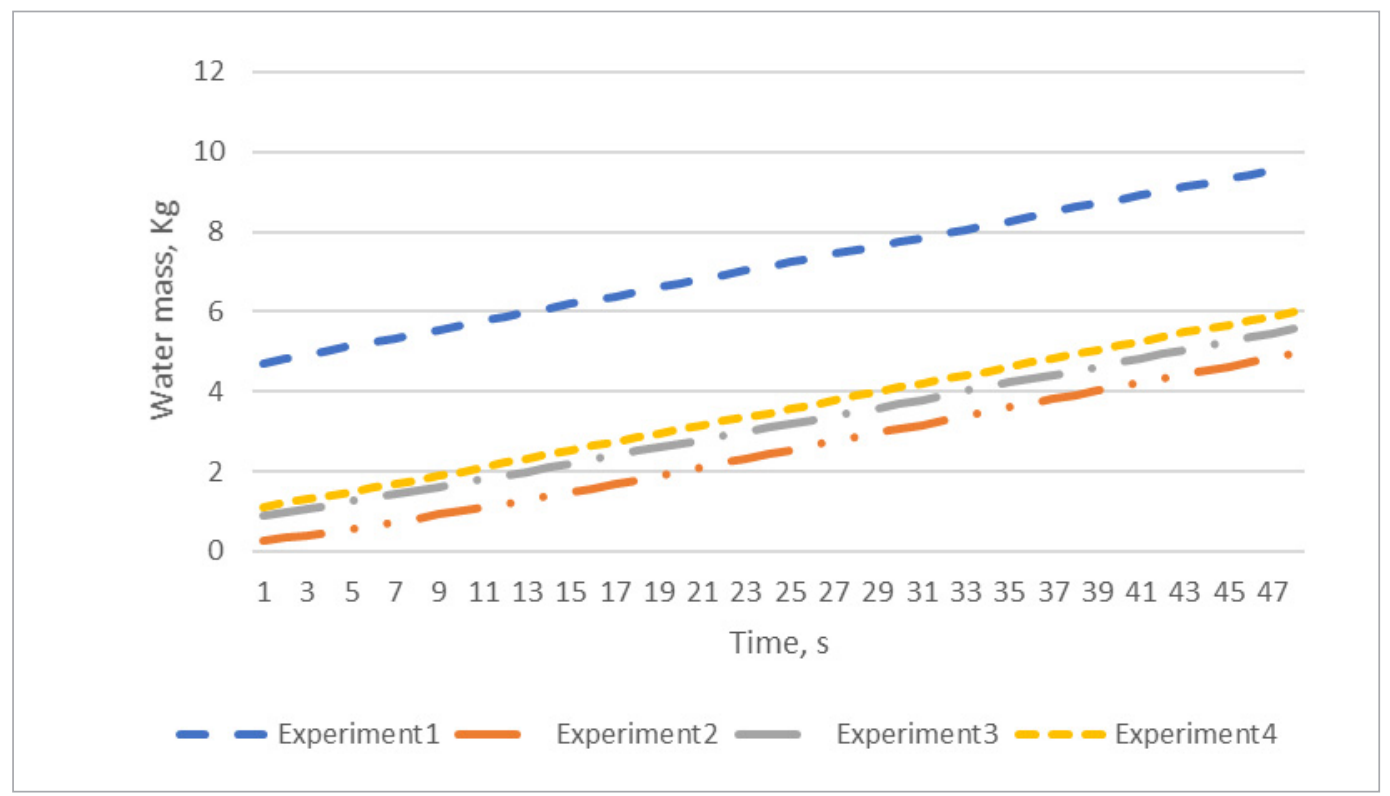

Fig. 6

Amount of water harvested during 4 experiments that were conducted in this study (Facade panel vertical)

Data was collected from the moment the water supply valve was opened to the moment it was closed. Due to air in the system, and the consequent unstable water flow at the beginning and end of the experiments, data that were not stable were removed from datasets. The amount of data deleted depended on each experiment. Only data with stable rainwater mass growth were used.

The simulated rain intensity was calculated using the method described above. After spraying all of the water into a bucket for 7.68 seconds, $870 \mathrm{~g}$ of water had been collected. This amount of water was chosen because of limitation of our water tank used for measuring it. This experiment showed that the water nozzle sprayed $0.113 \mathrm{~kg}$ of water each second. This equal to $0.14 \mathrm{~mm} /$ $\left(\mathrm{s}^{*} \mathrm{~m} 2\right)$ rain intensity. Such rain is classified as very violent rain and is an extreme case. In nature such rain intensity only happens for very short spans of time.

\section{Expanded stainless steel facade panel results}

The expanded metal facade panel was perforated, with $66 \%$ of the area comprising perforations. Calculations were made based on both the full dataset and for random, short time periods during the test. These were compared in order to ensure that the results were accurate and stable throughout the duration of the experiments. The main results are listed in Table 3.

As we can see from the Table 3, results show that $66.44 \%$ of all rainwater that hit the facade was successfully harvested when panel was vertical. $20.96 \%$ of all rainwater can also be potentially harvested by using external gutter that collects runoff water from the facade. Finally, less than $13 \%$ of all rainwater was not harvested and have splashed of the facade panel past the external gutter that is collecting facade runoff water.

\section{Angles impact on effectiveness of vertical rainwater harvesting system}

Additional experiments were conducted to analyze the impact of the angle of the facade on the effectiveness of the RWH system. Two additional angles were tested $-2.5^{\circ}$ and

\begin{tabular}{l|c}
\hline Duration of experiment $(\mathrm{s}):$ & 141 \\
\hline Rainwater harvested $\left(Q_{\text {harv }}\right):$ & $66.44 \%$ \\
\hline Rainwater runoff $\left(Q_{\text {runoff }}\right):$ & $20.96 \%$ \\
\hline All rainwater sprayed $\left(Q_{\text {rain }}\right):$ & $100 \%$ \\
\hline Harvested rainwater + runoff $\left(Q_{\text {harv }}+Q_{\text {runoff }}\right):$ & $87.40 \%$ \\
\hline Splashed off rainwater $\left(Q_{\text {splash }}\right):$ & $12.60 \%$ \\
\hline
\end{tabular}

\section{Table 3}

Results when facade panel is vertical 
Table 4

Angles impact on effectiveness on RWH system

\begin{tabular}{|c|c|c|}
\hline \multirow{6}{*}{$2.5^{\circ}$} & Duration of experiment (s): & 168 \\
\hline & Rainwater harvested $\left(Q_{\text {harv }}\right)$ : & $71.58 \%$ \\
\hline & Rainwater runoff( $\left.Q_{\text {runoff }}\right)$ : & $20.88 \%$ \\
\hline & All rainwater sprayed $\left(Q_{\text {rain }}\right)$ : & $100 \%$ \\
\hline & Harvested rainwater + runoff( $\left(Q_{\text {harv }}+Q_{\text {runoff }}\right):$ & $92.44 \%$ \\
\hline & Splashed off rainwater $\left(Q_{\text {splash }}\right)$ : & $7.54 \%$ \\
\hline \multirow{6}{*}{$7.5^{\circ}$} & Duration of experiment (s): & 147 \\
\hline & Rainwater harvested $\left(Q_{\text {harv }}\right)$ : & $79.72 \%$ \\
\hline & Rainwater runoff $\left(Q_{\text {runoff }}\right)$ : & $14.98 \%$ \\
\hline & All rainwater sprayed $\left(Q_{\text {rain }}\right)$ : & $100 \%$ \\
\hline & Harvested rainwater + runoff $\left(Q_{\text {harv. }}+Q_{\text {runoff }}\right)$ : & $94.70 \%$ \\
\hline & Splashed off rainwater $\left(Q_{\text {splash }}\right)$ : & $5.30 \%$ \\
\hline
\end{tabular}

$7.5^{\circ}$. Both angles were tested once. The period of these experiments was 2:30 minutes for each angle. No other parameters were changed, either in the experimental stand or the methodology. The results are compared in Table 4. As can be seen from Fig. 7, by increasing the angle, the percentage of harvested water also grew. This proved that the facade angle could have a significant impact on the effectiveness of such a system, even though completely vertical facades collects up to $87 \%$ of all rainwater.

\section{Fig. 7}

Comparison of different facade angles
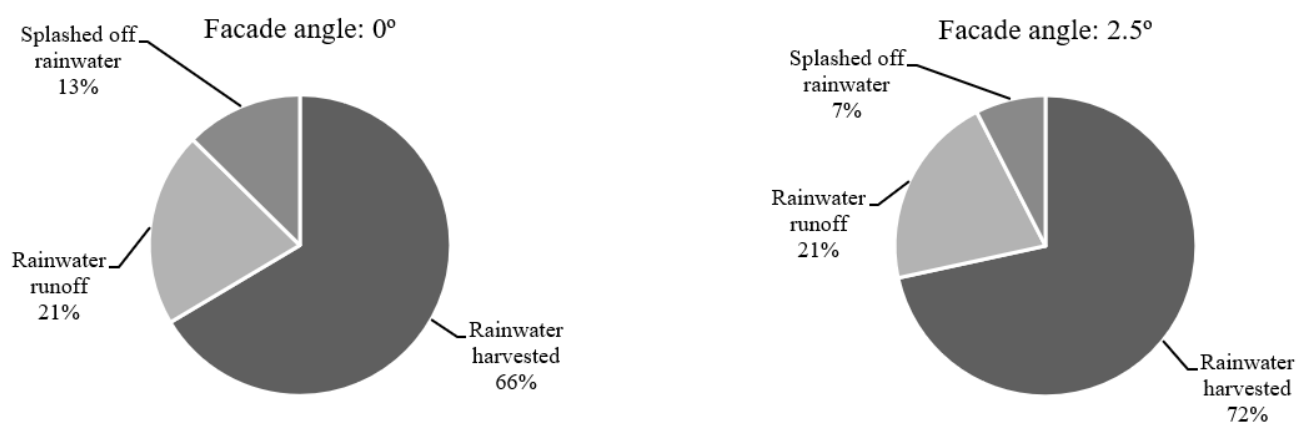

Facade angle: $7.5^{\circ}$

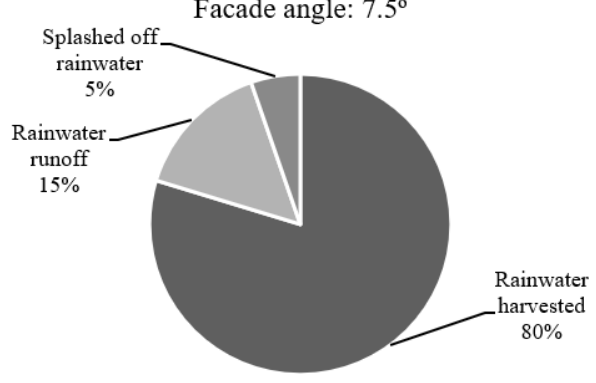


Although accurate data was collected and analysed, further studies are needed that will analyse how such a system will work under real (natural) conditions. This study only tested the situation where water droplets were hitting a facade panel with no horizontal angle, only vertical angle was used to simulate winds effect. Under real conditions, a building's facade angle is rarely perpendicular to the angle of the wind. This might have a significant impact on the effectiveness of this system, as more droplets need to hit the surface of the panel, rather than going straight through the perforations. Furthermore, our simulated rain intensity was very high and rarely occurs in nature. Additional experiments with lower rain intensity are required to evaluate if it has any significant impact on the effectiveness of the RWH system.

No tests have yet been performed using wind. Wind has a big impact on the speed and angle of the droplets. According to literature our experiments used an angle close to the one that occurs under real conditions during very windy rain. In order to fully analyse such a system, studies to evaluate the wind impact are also needed. Consequently, experiments with variable winds are needed, as well as tests that evaluate how wind gusts impact the amount of rainwater that is harvested.

Rain is highly dynamic, with a lot of variables, many of which could have a significant impact on the suggested vertical RWH system, so a lot of work is still left to do to fully evaluate such systems.

Based on data analysis conducted after all the experiments, the following main conclusions can be made:

- Wind driven rain harvesting system mounted on vertical facades can collect up to $66 \%$ off all rainwater that hits the panel when water flow is $0.113 \mathrm{l} / \mathrm{s}$ and water droplets hit the panel between $50^{\circ}$ and $65^{\circ}$

When rain droplets hit the panel between $50^{\circ}$ and $65^{\circ}$ with $0.113 \mathrm{l} / \mathrm{s}$ water flow, up to $21 \%$ of water runoffs the facade panel surface and can still be collected using external gutters

- Only $12.6 \%$ of water on average splashes off the facade and can't be harvested when it hits the panel between $50^{\circ}$ and $65^{\circ}$ with water flow of $0.113 \mathrm{l} / \mathrm{s}$

Increasing angle of the facade panels also increases the effectiveness of the RWH system. When facade panels were angled at $7.5^{\circ}$ systems effectiveness reached $80 \%$.

The authors are indebted to UAB "Morionis" for the supply of architectural panels that were employed for the purpose of this study.

The authors are also thankful to UAB "Šilnuta" for the supply of materials for the construction of the experimental stand's frame.

A. Kubilay, D. Derome, B. Blocken, J. Carmeliet, Wind-driven rain on two parallel wide buildings: Field measurements and CFD simulations. Journal of Wind Engineering and Industrial Aerodynamics, 2015; Volume 146: 11-28. https://doi.org/10.1016/j. jweia.2015.07.006

B. Blocken, D. Derome, J. Carmeliet. Rainwater runoff from building facades: A review. Building and Environment, 2013; Volume 60: 339-361. https://doi. org/10.1016/j.buildenv.2012.10.008

B. Blocken, J. Carmeliet. A review of wind-driven rain research in building science. Journal of
Wind Engineering and Industrial Aerodynamics, 2004; Volume 92, Issue 13: 1079-1130. https://doi. org/10.1016/j.jweia.2004.06.003

Kyllingstad, S. Thiis, T. Flø, A. Potac.). Climate, environment and frost damage of architectural heritage. 2010; 10.1201/b10428-233.

M. Abuku, H. Janssen, S. Roels, Impact of wind-driven rain on historic brick wall buildings in a moderately cold and humid climate: Numerical analyses of mould growth risk, indoor climate and energy consumption. Energy and Buildings, 2009; Volume 41, Issue 1: 101110. https://doi.org/10.1016/j.enbuild.2008.07.011

\section{Acknow- ledgment}

Discussion

Conclusions

\section{References}


S. Angrill, A. Petit-Boix, T. Morales-Pinzón, A. Josa, J. Rieradevall, X. Gabarrell. Urban rainwater runoff quantity and quality - A potential endogenous resource in cities?. Journal of Environmental Management, 2017; Volume 189: 14-21. https://doi. org/10.1016/j.jenvman.2016.12.027
Villarreal, Edgar \& Dixon, Andrew. Analysis of A Rainwater Collection System for Domestic Water Supply in Ringdansen, Norrkoping, Sweden. Building and Environment, 2005; 40: 1174-1184. https:// doi.org/10.1016/j.buildenv.2004.10.018

\section{About the} Authors

\section{MANTAS \\ DOBRAVALSKIS}

\section{Student}

Kaunas University of Technology, Faculty of Civil Engineering and Architecture

\section{Main research area}

Rain water harvesting, water resources, sustainable development

Address

Studentu st. 48, LT-51367 Kaunas, Lithuania Tel. +37060366536

E-mail: mantas. dobravalskis@ktu.lt

\section{PAULIUS SPŪDYS \\ Student}

Kaunas University of Technology, Faculty of Civil Engineering and Architecture

\section{Main research area}

Rain water harvesting, water resources, HVAC systems

\section{Address}

Studentu st. 48, LT-51367 Kaunas,

Lithuania

Tel. +37063665869

E-mail: p.spudys@gmail.com

\section{JUOZAS \\ VAIČIŪNAS}

Lecturer

Kaunas University

of Technology,

Department of

Civil Engineering

and Architecture competences center

Main research area

Water resources, water supply and disposal systems, hydronic performance of HVAC systems, renewable energy, structural stability of buildings.

\section{Address}

Studentu st. 48,

LT-51367 Kaunas,

Lithuania

Tel. +37061556760

E-mail: juozas.

vaiciunas@ktu.lt

\section{PARIS FOKAIDES}

\section{Chief Researcher}

Kaunas University of Technology, Faculty of Civil and Environmental Engineering

Main research area

Sustainable Energy in the Built Environment

\section{Address}

Studentu st. 48, LT-51367 Kaunas, Lithuania Tel. +35799793207 E-mail: paris.fokaides@ktu.lt 